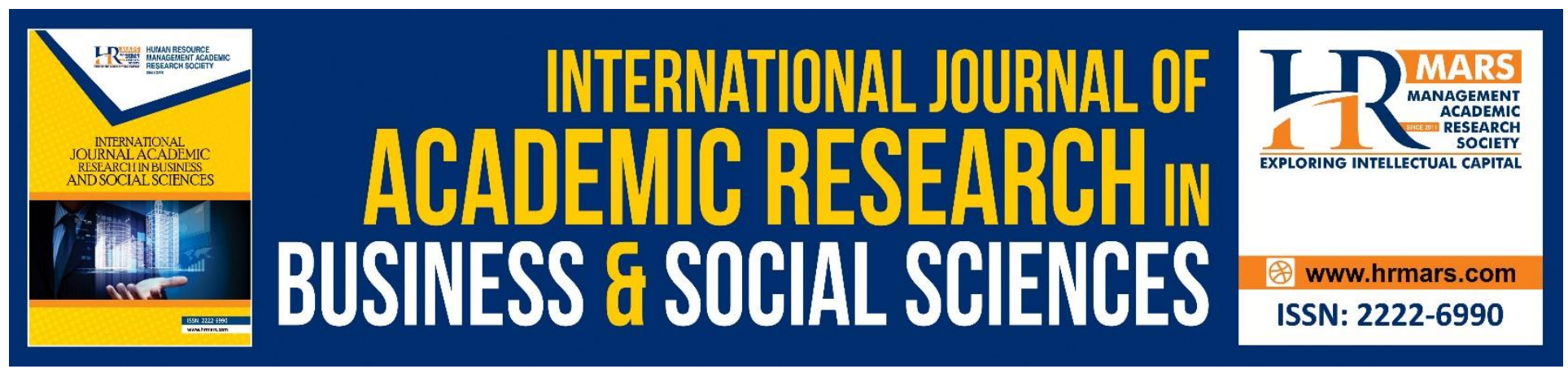

\title{
Potential Users' Acceptance of Shariah-Compliant Precious Metal Backed Crypto Currency: A Malaysian Perspective
}

Faeyz M.J Abuamria, Mousa A.M Ajouz

To Link this Article: http://dx.doi.org/10.6007/IJARBSS/v10-i7/7411

DOI:10.6007/IJARBSS/v10-i7/7411

Received: 16 April 2020, Revised: 21 May 2020, Accepted: 14 June 2020

Published Online: 25 July 2020

In-Text Citation: (Abuamria, 2020)

To Cite this Article: Abuamria, F. M. . M. A. . A. (2020). Potential Users' Acceptance of Shariah-Compliant Precious Metal Backed Crypto Currency: A Malaysian Perspective. International Journal of Academic Research in Business and Social Sciences, 10(7), 224-231.

Copyright: @ 2020 The Author(s)

Published by Human Resource Management Academic Research Society (www.hrmars.com)

This article is published under the Creative Commons Attribution (CC BY 4.0) license. Anyone may reproduce, distribute, translate and create derivative works of this article (for both commercial and non-commercial purposes), subject to full attribution to the original publication and authors. The full terms of this license may be seen

at: http://creativecommons.org/licences/by/4.0/legalcode

Vol. 10, No. 7, 2020, Pg. 224 - 231

http://hrmars.com/index.php/pages/detail/IJARBSS

JOURNAL HOMEPAGE

Full Terms \& Conditions of access and use can be found at http://hrmars.com/index.php/pages/detail/publication-ethics 


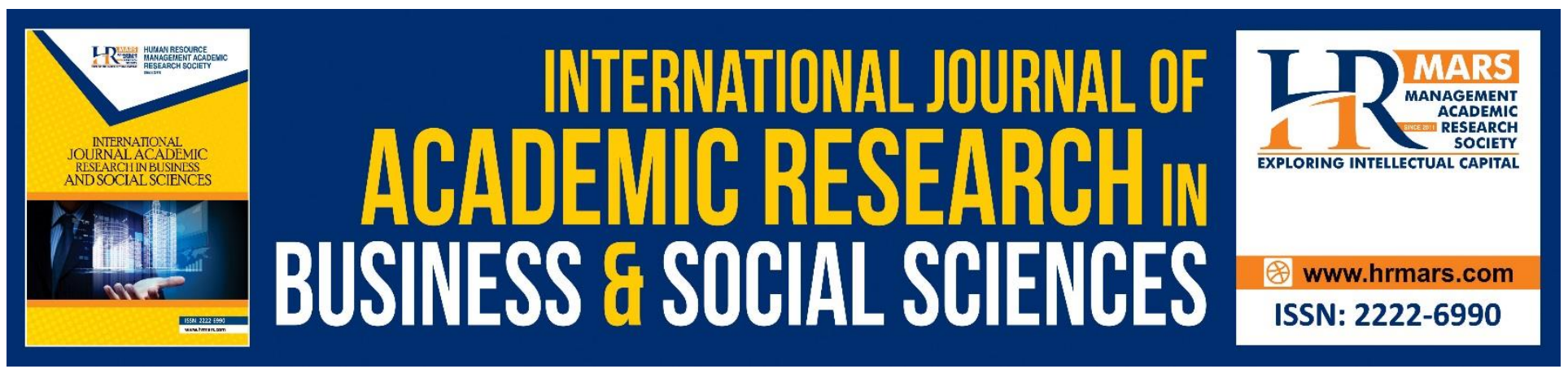

\title{
Potential Users' Acceptance of Shariah-Compliant Precious Metal Backed Crypto Currency: A Malaysian Perspective
}

\author{
Faeyz M.J Abuamria ${ }^{1}$, Mousa A.M Ajouz ${ }^{2}$ \\ ${ }^{1}$ Assistant Professor, Department of Finance, Palestine Ahliya University, ${ }^{2}$ Assistant Professor, \\ College of Administrative Sciences and Informatics, Palestine Polytechnic University, Hebron, \\ Palestine.
}

Email: f.abuamria@paluniv.edu.ps,mousa-ajouz@hotmail.com

\begin{abstract}
Recent developments in crypto currency have heightened the emergence and development of a new forms of money generally and crypto currency particularly. This development has reached to the precious metal, which is historically known as money. Reusing precious metal as money by benefiting from crypto currencies technology is perceived to be an innovation in the current payment system that abandoned precious metal as money since 1973. Therefore, the aim of this research is to investigate the potential users' tendency to adopt a Shariah-compliant precious metal-backed crypto currency. The methodological approach adopted in this study is a quantitative method using questionnaires that were built based on the original model of innovation diffusion theory, which consists of five factors. The analysis was conducted based on data elicited from 92 questionnaires using PLS-SEM. Overall, the results indicate that four out of the five constructs that specified to affect the adoption of PMBC were statistically significant. 50.4 percent of the differences in the adoption of PMBC can be explained by the structural model provided by this research. Just over half of the respondents (63.35) reported that they are willing to use PMBC in their future transaction. It is recommended that further empirical investigations be undertaken using alternative theories and methods.
\end{abstract}

Keywords: Shariah - Compliant, Precious Metal, Crypto currency, Malaysia, Adoption Model.

\section{Introduction}

At the beginning of the 2007 international financial crisis, criticizers analysed different approaches to transfer value that decentralised, trust-less currency, that is not reliant on central authority (Abuamria et al., 2018; Maurer et al., 2013; Mullan, 2014). Therefore, on 3 January 2009, Satoshi

\footnotetext{
${ }^{1}$ Assistant Professor, Department of Finance, Palestine Ahliya University, f.abuamria@ paluniv.edu.ps ${ }^{2}$ Assistant Professor, College of Administrative Sciences and Informatics, Palestine Polytechnic University, Hebron, Palestine, mousa-ajouz@ hotmail.com.
} 
Nakamoto presented the first crypto currency in the world, which called Bitcoin (Nakamoto, 2008). The market of crypto currency has grown-up and developed unsteadily and promptly over the shortterm since the launch of Bitcoin (Farell, 2015). As early as 2020, more than 2518 varied types of crypto currencies emerged as never happened before, with a market valued exceeded USD 260 billion (CoinMarketCap, 2020).

Although crypto currencies customarily and Bitcoin specifically have appeared to solve the problems created by fiat money, it had only partly resolved the problem. However, it boosted other issues and challenges, on the contrary crypto currencies were preferred targets for risk-takers, manipulators, and illegitimate business, which led to disastrous instabilities in its value. For example, on 18 December 2017, the value of one Bitcoin has radically plummeted during six days from UDS 19,298to USD 13,206 (CoinMarketCap, 2020). Currently, 2 July 2020, the one Bitcoin is trafficked at USD 9,099 which show the huge instabilities in its value. Moreover, it has been found that crypto currencies have many Shariah concerns, which derived some countries for banning some of these currencies (Al-Qaradaghi, 2018; Islamic Economy Forum, 2018).

These topics were encouraging to examine other options by developing valuable metalbacked crypto currency to overcome the instability of value. The precious metal has been conserved its value, as confirmed by history, that metal stayed steady and trusted by the economy (Abdullah, 2016b). Generally speaking, the idea of precious metal-backed crypto currency PMC is an electronic representation of precious physical metal held offline in a safe cellar as users are circulating the encrypted electronic units. It offers efficient and protected online methods to sell, buy, hold, spend, earn, send, and redeem gold and silver (Ajouz et al., 2020b). Until the written of these lines, there almost 111 different types of assets backed crypto currency has introduced in various countries and jurisdictions (James, 2020). Interestingly enough, two of these companies, such as Hello Gold and One Gram Coin have been approved to be Shariah-compliant (HelloGold, 2018; OneGram, 2018).

Presenting of precious metal-backed crypto currency is supposed to be an innovation among the world's payment system (Ajouz et al., 2020a; Yusuf et al., 2013). That is because after the downfall of the Bretton Woods system in the early 1970s, the precious metals were not used as a currency, and the concept of crypto currency has only arisen in early 2009. Therefore, it is essential to examine the potential users' views to understand from the demand viewpoint if the potential users are willing to adopt precious metal-backed crypto currency based on innovation diffusion theory (IDT).

This paper is arranged as follows: it first starts with the introduction of the paper, then it presents the review of related literature followed by the used methodology of the study. The last section presents a discussion and the findings of the study, followed by a conclusion and some recommendations.

\section{Literature Review \\ Relative Advantage}

Relative advantage refers to "the extent by which an innovation is perceived as better than the idea it replaces" (Rogers, 2003:29). Precious metal as money has proved its capability to preserves wealth and value throughout the long run. Given their stability, gold and silver can perform a vital role as money; at the same time precious metals can protect from inflation and ensure price stability (Abdullah, 2016a; Ajouz et al., 2020b; Meera, 2002, 2004). As a result, this study hypothesizes that:

$\mathbf{H}_{1} \quad$ Relative advantage of using precious metal-backed crypto currency will have a positive effect on its adoption. 
INTERNATIONAL JOURNAL OF ACADEMIC RESEARCH IN BUSINESS AND SOCIAL SCIENCES Vol. 10, No. 7, July, 2020, E-ISSN: 2222-6990 @ 2020 HRMARS

\section{Compatibility}

Compatibility refers to "the extent by which an innovation is perceived as being compatible with the current values, needs of possible adopters, and past experiences" (Rogers, 2003:240). PMBC could be compatible with the lifestyle of current generation, values and sociocultural beliefs, this mainly because gold and silver are money by itself, and the desire to accumulating them did not fade away (Ajouz et al., 2020a). Therefore, this research proposes that:

$\mathrm{H}_{2} \quad$ Compatibility of using precious metal-backed crypto currency will have a positive effect on its adoption.

\section{Anxiety}

Anxiety refers to "the extent by which an innovation is perceived as relatively difficult to use and understood" (Rogers, 2003:257). The complexity factor in PMBC mainly associated with the precious metal (Ajouz et al., 2020a; Yusuf et al., 2013). According to Yusuf et al. (2013:100-101), there are three main challenges obstruct implementing gold dinar as a currency that are exchange risks, price volatility, and political risk. As a result, this research proposes that:

$\mathrm{H}_{3} \quad$ Anxiety of using precious metal-backed crypto currency would have a negative effect on its rate of adoption.

\section{Trialability}

Trialability refers to "the extent by which an innovation may be experimented with on a limited basis before adoption" (Rogers, 2003:258). PMBC is a completely different form of money that individuals are used to. Potential users need to experiment with the consequences of PMBC before choosing to use it (Ajouz et al., 2020a; Karahanna et al., 1999). Hence, giving potential users the opportunity to try PMBC would enhance the adoption process. Because of this, this study hypothesizes that:

$\mathrm{H}_{4} \quad$ Trialability of using precious metal-backed crypto currency will have a positive effect on its adoption.

\section{Observability}

Observability refers to "the degree to which the results of an innovation are visible to others". Thus, some ideas are easy to observe, described, and communicate among society members about theses inventions, while other inventions are much difficult to be observed or described by society member (Rogers, 2003:258). Thus, the usage rate of any new invention would increase significantly if the potential adopters can easily able to observe and describe the value added by the new payment mechanism, which is PMBC (Ajouz et al., 2020a; Yusuf et al., 2015). Therefore, this study hypothesizes that:

$\mathrm{H}_{5} \quad$ Observability of using precious metal-backed crypto currency will have a positive effect on its adoption.

\section{Materials and Methods}

This research was conducted in Klang Valley, Malaysia. The potential users are the primary target respondents who are the active economic residents in Klang Valley. The study also adopted a judgment sampling as a sampled frame, where the selection criteria were mainly based on their uses of electronic payment procedure, either debit or/and credit cards, mobile payment online banking, cryptocurrency, or electronic money. In addition, they are aged above 20 years, permeant residents 
INTERNATIONAL JOURNAL OF ACADEMIC RESEARCH IN BUSINESS AND SOCIAL SCIENCES

Vol. 10, No. 7, July, 2020, E-ISSN: 2222-6990 @ 2020 HRMARS

or residents of Klang Valley; this criterion is similar to the one used by Ajouz et al. (2020a). Given that, with a five percent margin error and 95 percent confidence level, the minimum sample size that was recommended by Hair et al. (2016:20) for this type of research is 50 . Using a self-administered and trained enumerator, a total of 110 questionnaires were distributed to selective potential users in Klang Valley. Eighteen questionnaires were not included in the data analysis because they did not meet the selection criteria adopted in this research. Therefore, 92 questionnaires were analyzed.

The demographic results obtained from the 92 respondents showed that around 51.1 percent of the respondents are male, and the rest (48.9\%) are female. Interestingly, the younger generations who aged between 20 years and 40 years are dominated on the sample with $90.3 \%$, while only $9.7 \%$ of the respondents above 41 years. Malaysian society is very well known for its ethnic compositions, which were reflected in the sample; as such majority of the respondents were Muslims (62.3\%), Buddhist present 25.0\%, while 3.3 and 1.3 percent of Hindus and Christians, respectively. The themes of monthly income showed that more than $80 \%$ of the respondents are from middle-class income who have less than RM5,000 per month, meanwhile around $19.6 \%$ earn above that per month. In terms of distribution of the respondents by educational level, the majority of the respondent $(87 \%)$ are well educated where they are holding at least diploma certificates or higher certificate while the rest are having school education. The demography profile of the respondents revealed their belonging to different occupation categories encompassing $40.2 \%$ are self-employed, while $40.2 \%$ are working in civil servants and private sector, followed by students who present $12 \%$, and 7.6 are still looking for opportunities.

\section{Results}

\section{The Measurement Models}

The fit of hypothesized model was evaluated based on confirmatory factor analysis through partial least squares (PLS) in Smart-PLS 3 (Ringle et al., 2015). The 92 sampled data collected from potential users of Shariah-compliant precious metal-backed crypto currency. As suggested by Hair et al. (2016), the assessment of the model was conducting for indicator reliability, internal consistency, as well as convergent and discriminant validity.

First of all, indicator reliability was conducted according to Hair et al. (2016) criteria, where each indicator must have outer loadings of 0.70 or greater. Some items were eliminated because they were not qualified by this criterion, the remaining items (shown in Fig 1) were having outer loading between 0.70 and 0.92 , and all the indicators were statistically significant at 0.00 . These results indicate that the instrument is having indicator reliability. Secondly, Cronbach's alpha and composite reliability were used to evaluate the internal consistency reliability. The results of Cronbach's alpha for all constructs were between 0.728 and 0.865 . Additionally, the results of composite reliability for all constructs were between 0.849 and 0.912 . Accordingly, the above results represent acceptable internal consistency reliability according to Hair et al. (2016) criteria.

According to the validity evidence, the validity of the hypothesized model was established using convergent and discriminant validity. Firstly, the average variance extracted (AVE) was carried out to ensure convergent validity. The results of AVE were above 0.50 , indicating that the convergent validity was established according to Hair et al. (2016) criteria, where the value of AVE were between 0.598 and 0.775 . Whilst discriminant validity was evaluated based on three approaches, which are observing the cross-loading of the items, Fornell-Larcker criteria, and heterotrait-monotrait ratio of correlations (HTMT) criteria (Hair et al., 2016, 2019). Firstly, by evaluating the items and construct 
loading and cross-loading, it shows that all items and construct in their respective items and construct have factorial and construct loads higher than any other items and construct which indicate the establishment of discriminant validity based on loading and cross loading criteria, and Fornell-Larcker criteria (Chin, 1998). Secondly, by evaluating the results of discriminant validity based on HTMT criteria, it was found that all results of construct were below 0.85 , and all the indicators were statistically significant from 1 , which according to Kline, (2011) criteria achieve the discriminant validity. All in all, the results of the hypothesized measurement model are satisfactory, which can be used in the structural model analysis to test the hypothesis of this research.

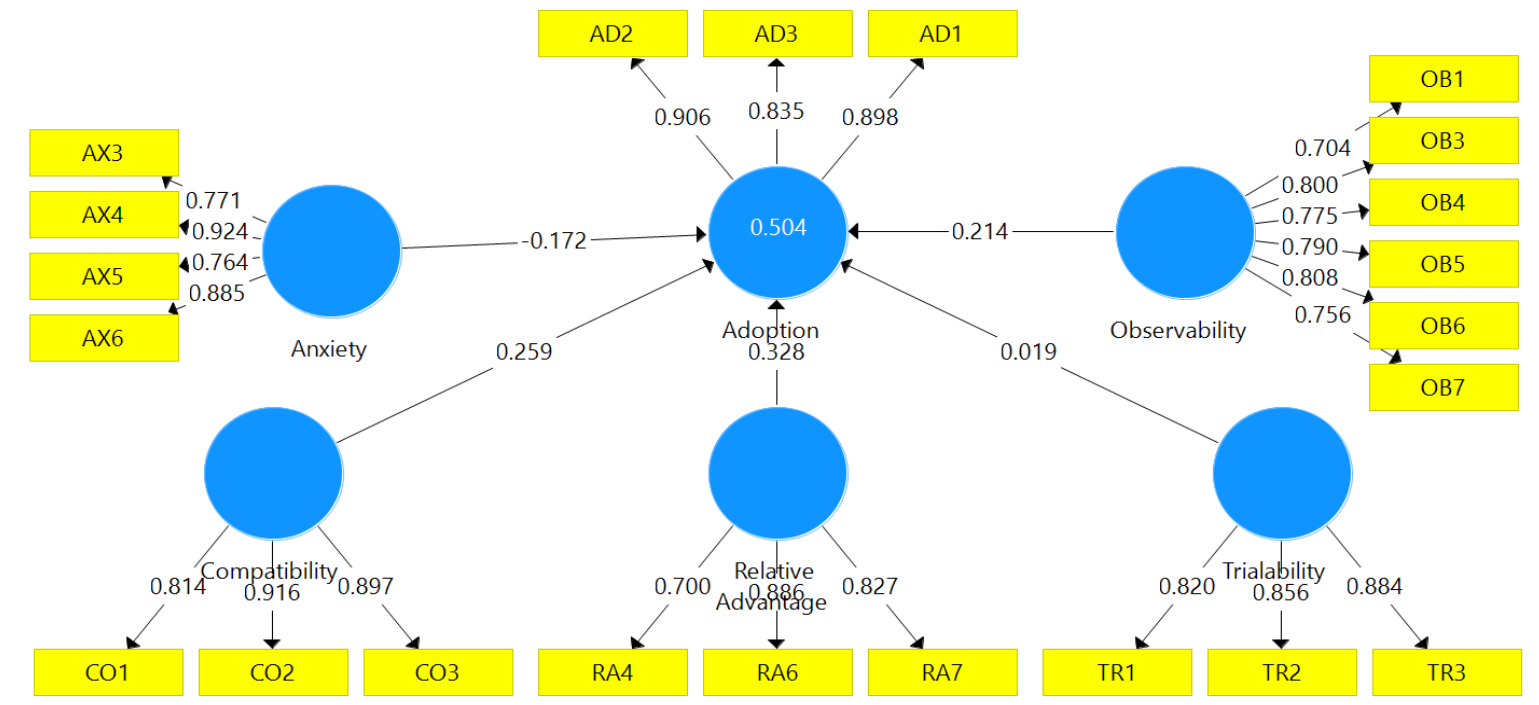

Figure 1: PLS-SEM with the values of the t-tests obtained via the Bootstrapping module

\section{The Structural Model: Assessing the Adoption of Precious Metal Backed Crypto Currency}

It is apparent from Table 1 below that there was a significant positive correlation between adoption of PMC and relatively advantage where the $\beta=0.322 ; t=3.073, P<0.05$. The result indicates that the potential users believe they will have relative advantages by using and adopting of PMC in their daily transactions. In addition, on average, compatibility was shown to have positive correlation on the adoption of PMC as $\beta=0.261 ; t=2.356, P<0.05$. The respondents found to be believing in PMC to compatible with their current values, needs, and past experiences. However, a negative correlation was found between anxiety and adoption of PMC, where the hypotheses found supported with a negative sign as was expected where $\beta=-0.177 ; t=2.136, P<0.05$. This means that the more difficulty and complexity attached to the precious metal-backed crypto currency, the fewer users' willingness to adopt it in their future transaction. Further statistical tests revealed a positive effect of observability on adoption of $P M C$ as $\beta=0.215 ; t=2.475, P<0.05$. The potential users found to be able to observe the results and gains of adopting PMC.

Unexpectedly, there were no significant differences between trialability and adoption of PMC where $\beta=0.030 ; t=0.220, P>0.05$. According to Yusuf et al. (2015), giving potential users the chance to try PMC before full adoption increase their wiliness to adopted PMC completely in the future, but such a relationship was not confirmed by the collected data. However, testing the hypothesis using the Kruskal-Wallis Test was found to be statistically significant as Chi-Square $=18.977 ; 4$, Asymp. Sig $<0.05$. 
INTERNATIONAL JOURNAL OF ACADEMIC RESEARCH IN BUSINESS AND SOCIAL SCIENCES Vol. 10, No. 7, July, 2020, E-ISSN: 2222-6990 @ 2020 HRMARS

Table 1: PLS-SEM Results: Path Coefficients of the Adjusted Model

\begin{tabular}{|c|c|c|c|c|c|}
\hline Hypotheses & Relationship & Std Beta & Std Error & T-Value & Decision \\
\hline$H_{R A}$ & $\begin{array}{c}\text { Relative Advantage -> } \\
\text { Adoption }\end{array}$ & 0.322 & 0.107 & 3.073 & Supported \\
\hline $\mathbf{H}_{\mathrm{CO}}$ & $\begin{array}{c}\text { Compatibility }-> \\
\text { Adoption }\end{array}$ & 0.261 & 0.110 & 2.356 & Supported \\
\hline $\mathbf{H}_{\mathrm{AX}}$ & Anxiety $->$ Adoption & -0.177 & 0.081 & 2.136 & Supported \\
\hline $\mathbf{H}_{\mathrm{TR}}$ & $\begin{array}{l}\text { Trialability -> } \\
\text { Adoption }\end{array}$ & 0.030 & 0.087 & 0.220 & $\begin{array}{c}\text { Not } \\
\text { Supported }\end{array}$ \\
\hline $\mathrm{H}_{\mathrm{OB}}$ & $\begin{array}{c}\text { Observability -> } \\
\text { Adoption }\end{array}$ & 0.215 & 0.086 & 2.475 & Supported \\
\hline
\end{tabular}

\section{Conclusion}

The present research was designed to determine the factors that influencing the adoption of Shariahcompliant precious metal-backed crypto currency. This study has found that generally four out of the five constructs were found to be statistically significant where relative advantage, compatibility, and observability found to be positively influencing the adoption of PMC, while anxiety was negatively influencing the adoption of PMC. Surprisingly, only trialability was found not statistically significant based on the collected data. The second major finding was that $50.4 \%$ of the differences in the adoption of PMC were explained by the structure model proposed in the current study. The results of this investigation also showed that around $63.55 \%$ of the respondents are willing to adopt PMC in their future transactions. The exploratory results of hypotheses found that four out of the five constructs were found to be statistically significant. Therefore, it is suggested that other research should be conducted using confirmatory methods. In addition, the current investigation was limited to the use of innovation diffusion theory (IDT) in Malaysia. Further studies, which use other theories, are therefore suggested.

The finding of this research contributes to existing knowledge that benefits the researchers, proponents and practitioners of Islamic economics, banking, and finance. This is because in the era of cryptocurrency, it is important to offer a Shariah-compliant crypto currency and understand the factors that influence potential users' decision in adopting this crypto currency. In addition, Islamic finances are much in their desire to focus on real assets and real economy (Farooq \& Selim, 2019). Therefore, this crypto currency would contribute in this manner.

\section{References}

Abdullah, A. (2016a). An Islamic monetary theory of value and equation of exchange: evidence from Egypt (696-1517). Humanomics, 32(2), 121-150.

Abdullah, A. (2016b). The Islamic Currency (1th ed.). Kuala Lumpur, Malaysia: International Council of Islamic Finance Educators.

Abuamria, F., Shadid, M., \& Jaradat, N. (2018). The effect of the Digital currency (Bitcoin) in reducing the costs of Electronic purchase. Al-Utroha, 5, 87-115.

Ajouz, M., Abdullah, A., \& Kassim, S. (2020a). Acceptance of Shariah-compliant precious metal-backed cryptocurrency as an alternative currency: An empirical validation of adoption of innovation theory. Thunderbird International Business Review, 62(2), 171-181.

Ajouz, M., Abdullah, A., \& Kassim, S. (2020b). Developing a Shariah-Compliant Precious Metal Backed 
INTERNATIONAL JOURNAL OF ACADEMIC RESEARCH IN BUSINESS AND SOCIAL SCIENCES

Vol. 10, No. 7, July, 2020, E-ISSN: 2222-6990 @ 2020 HRMARS

Cryptocurrency. Journal of King Abdulaziz University, Islamic Economics, 33(1), 3-20.

Al-Qaradaghi, A. (2018). Fatwa on the Islamic Ruling on Cryptocurrency. Private Office.

CoinMarketCap. (2020). Cryptocurrencies by Market Capitalization. Retrieved July 1, 2020, from CoinMarketCap: www.coinmarketcap.com

Farell, R. (2015). An analysis of the cryptocurrency industry. In Wharton Research Scholars. Philadelphia, Pennsylvania: Wharton Research Scholars.

Farooq, M. O., \& Selim, M. (2019). Conceptualization of the real economy and Islamic finance: Transformation beyond the asset-link rhetoric. Thunderbird International Business Review, 61(5), 685-696.

Hair, J. F., Hult, G. T. M., Ringle, C., \& Sarstedt, M. (2016). A primer on partial least squares structural equation modeling (PLS-SEM). Thousand Oaks, California: Sage publications.

Hair, J. F., Sarstedt, M., \& Ringle, C. M. (2019). Rethinking some of the rethinking of partial least squares. European Journal of Marketing, 53(4), 566-584.

HelloGold. (2018). About Us. Retrieved July 22, 2020, from HelloGold: www.hellogold.com

Islamic Economy Forum. (2018). Islamic Economy Forum Statement on the Legitimacy of Bitcoin. Islamic Economy Forum.

James. (2020). A guide to gold-backed cryptocurrency. Retrieved July 2, 2020, from Goldscape. Net: www.goldscape.net

Karahanna, E., Straub, D. W., \& Chervany, N. L. (1999). Information technology adoption across time: a cross-sectional comparison of pre-adoption and post-adoption beliefs. MIS Quarterly, 23(2), 183-213.

Kline, R. B. (2011). Principles and practice of structural equation modeling. New York, USA: Guilford Press.

Maurer, B., Nelms, T. C., \& Swartz, L. (2013). When perhaps the real problem is money itself!: the practical materiality of Bitcoin. Social Semiotics, 23(2), 261-277.

Meera, A. K. (2002). The Islamic gold dinar. Subang Jaya, Malaysia: Pelanduk Pubns Sdn Bhd.

Meera, A. K. (2004). The Theft of Nations: Returning to Gold. Subang Jaya, Malaysia: Pelanduk Pubns Sdn Bhd.

Mullan, P. (2014). The Digital Currency Challenge: Shaping Online Payment Systems Through US Financial Regulations. Hampshire, England: Palgrave Macmillan.

Nakamoto, S. (2008). Bitcoin: A peer-to-peer electronic cash system. White paper.

OneGram. (2018). First OneGram Transaction Made. Retrieved July 22, 2020, from Onegram: www.onegram.org

Ringle, C. M., Wende, S., \& Becker, J.-M. (2015). "SmartPLS 3." Boenningstedt: SmartPLS GmbH. Retrieved July 22, 2020, from smartpls: www.smartpls.com

Rogers, E. M. (2003). Diffusion of innovations (5th ed.). New York, USA: The Free Press.

Yusuf, M. B., Ghani, G. M., \& Meera, A. K. (2013). The challenges of implementing gold dinar in Kelantan: An empirical analysis. International Journal of Institutions and Economics, 5(3), 97114.

Yusuf, M. B., Meera, A. K., Ghani, G. M., Manap, T. A., \& Larbani, M. (2015). Acceptance of Gold as an Alternative Currency: An Empirical Validation of Adoption of Innovation Theory. Asian Journal of Business and Accounting, 8(2), 123-154. 